\title{
Pathophysiology of Migraine - New Insights
}

\author{
RJ Hargreaves and SL Shepheard
}

\begin{abstract}
Current theories propose that the primary dysfunction in migraine occurs within the CNS and that this evokes changes in blood vessels within pain-producing intracranial meningeal structures that give rise to headache pain. Migraine is now thought of as a neurovascular disorder. It has been proposed that genetic abnormalities may be responsible for altering the response threshold to migraine specific trigger factors in the brain of a migraineur compared to a normal individual. The exact nature of the central dysfunction that is produced in migraineurs is still not clear and may involve spreading depression-like phenomena and activation of brain stem monoaminergic nuclei that are part of the central autonomic, vascular and pain control centers. It is generally thought that local vasodilatation of intracranial extracerebral blood vessels and a consequent stimulation of surrounding trigeminal sensory nervous pain pathways is a key mechanism underlying the generation of headache pain associated with migraine. This activation of the 'trigeminovascular system' is thought to cause the release of vasoactive sensory neuropeptides, especially CGRP, that increase the pain response. The activated trigeminal nerves convey nociceptive information to central neurons in the brain stem trigeminal sensory nuclei that in turn relay the pain signals to higher centers where headache pain is perceived. It has been hypothesized that these central neurons may become sensitized as a migraine attack progresses. The 'triptan' anti-migraine agents (e.g. sumatriptan, rizatriptan, zolmitriptan naratriptan) are serotonergic agonists that have been shown to act selectively by causing vasoconstriction through 5 -HT 1 receptors that are expressed in human intracranial arteries and by inhibiting nociceptive transmission through an action at 5-HT $\mathrm{T}_{1 \mathrm{D}}$ receptors on peripheral trigeminal sensory nerve terminals in the meninges and central terminals in brain stem sensory nuclei. These three complementary sites of action underlie the clinical effectiveness of the 5- $\mathrm{HT}_{1 \mathrm{~B} / 1 \mathrm{D}}$ agonists against migraine headache pain and its associated symptoms.
\end{abstract}

RÉSUMÉ: Physiopathologie de la migraine - Nouveaux concepts. Les théories actuelles proposent que la dysfonction primaire dans la migraine est localisée dans le SNC et qu'elle provoque des changements dans les vaisseaux sanguins localisés dans les structures méningées intracrâniennes produisant ainsi la douleur. La céphalée résulte de ces changements. On pense maintenant que la migraine est un désordre neurovasculaire. Des anomalies génétiques pourraient être responsables de l'altération du seuil de la réponse aux facteurs spécifiques déclenchant la migraine dans le cerveau d'un migraineux comparé à un individu normal. La nature exacte de la dysfonction centrale chez les migraineux n'est pas encore claire et pourrait impliquer un phénomène qui se propage ressemblant à la dépression et à l'activation des noyaux monoaminergiques du tronc cérébral qui font partie des centres autonomes, vasculaires et du contrôle de la douleur. On pense en général que la vasodilatation locale des vaisseaux sanguins intracrâniens extracérébraux et une stimulation des voies sensitives nociceptives adjacentes du trijumeau constituent un mécanisme clé dans la production de la céphalée associée à la migraine. On pense que cette activation du "système trigéminovasculaire" provoque la libération de neuropeptides sensitifs vasoactifs, spécialement du CGRP qui augmente la réponse douloureuse. Les nerfs trijumeaux activés amènent l'information nociceptive aux neurones centraux situés dans les noyaux sensitifs trigéminés du tronc cérébral qui, à leur tour, relayent les signaux douloureux aux centres supérieurs où la douleur est perçue. On a émis l'hypothèse que ces neurones centraux peuvent devenir sensibilisés à mesure que l'accès de migraine progresse. Les agents antimigraineux de la famille du triptan (sumatriptan, rizatriptan, zolmitriptan, naratriptan) sont des agonistes sérotoninergiques dont l'action sélective sur les récepteurs 5- $\mathrm{HT}_{1 \mathrm{~B}}$, exprimés dans les artères intracrâniennes humaines, cause une vasoconstriction et inhibe la transmission nociceptive par leur action sur les récepteurs 5-HT 1 situés sur les terminaisons nerveuses sensitives périphériques du trijumeau dans les méninges et sur les terminaisons centrales dans les noyaux sensitifs du tronc cérébral. Ces trois sites complémentaires d'activité expliquent l'efficacité clinique des agonistes $5-\mathrm{HT}_{1 \mathrm{~B} / 1 \mathrm{D}}$ contre la migraine et ses symptômes associés.

Can. J. Neurol. Sci. 1999; 26: Suppl. 3-S12-S19

The specific cause of common forms of migraine headache is unknown but studies on families suffering from familial hemiplegic migraine (FHM) have suggested that genetic factors may be involved. ${ }^{1,2}$ In FHM, a rare subtype of migraine with aura, missense mutations in a neuronal specific P/Q calcium channel gene that give rise to amino acid substitutions in the pore-forming and voltage sensor regions of the alpha 1a subunit of the channel have been identified. It was hypothesized that these changes may provide the basis for channel and consequent brain dysfunction in FHM sufferers. Recent studies from Hans and colleagues ${ }^{3}$ have shown that these mutations produce a constellation of changes in channel expression and kinetics that result both in a net gain and a net loss of function. FHM is

From Merck Research Laboratories, West Point PA USA (RJH) and Merck Sharp and Dohme, Neuroscience Research Centre, Harlow, Essex, UK (RJH, SLS)

Reprint requests to: RJ Hargreaves, Merck Research Laboratories, PO Box 4, Sumneytown Pike, West Point PA 19486 USA. 
thought to be a genetically simple (autosomal dominant) disorder, whereas the more common migraine variants are likely to be genetically complex (multifactorial polygenic) with a substantial influence from 'environmental factors' that increase genetic penetrance to produce the observed phenotype. The study of FHM has nonetheless given a framework for the study of other migraine disorders (see review by Kathy Gardner, this supplement). There is, however, no doubt that deciphering the genetic basis of common migraine with and without auras is going to be a monumental task.

It has been suggested that it is theoretically possible for all individuals to suffer a migraine attack. The occurrence and frequency of attacks in any individual will be governed by the responsivity of their CNS to migraine specific triggers (e.g. certain foods, hormones, changes in levels of stress, consciousness and even exposure to light and sound). It has been hypothesized that genetic abnormalities result in a lowered threshold of response to these specific trigger factors in migraineurs. The trigger factors can thus be conceptualized as modulators of the genetic set point that predisposes to migraine. Conversely, in normal individuals, who lack genetic deficits relevant to migraine, exposure to the same trigger factors would not breach the 'migraine threshold' and so an attack would not be initiated. It is possible that the abnormal hyper-responsivity of the brain of migraineurs, like FHM, may be a consequence of genetic abnormalities in ion channels that regulate neuronal excitability. This has given rise to the description of migraine as a channelopathy. ${ }^{4}$

The theory suggests that, as a result of this channelopathy, migraine specific triggers can provoke marked CNS dysfunction that can characterize and initiate the early stages of a migraine attack. In this respect, the presence of blood flow changes, both oligemia and hyperaemia, have been taken to be indicative of altered CNS activation and have supported a role for spreading depression, or indeed activation, in migraine (particularly with aura) pathogenesis. ${ }^{5,6,7,8}$ It is interesting to speculate that the presence or absence of aura may also reflect a threshold phenomenon that is determined by the extent of the early CNS dysfunction produced by migraine trigger factors. Such an explanation could accommodate those patients who present symptoms of migraine with aura and migraine without aura. The first clear observation in support of the integrated hypothesis was that patients with no history of migraine developed migraine-like episodes after surgery to implant electrodes in the periaqueductal grey matter and raphe nuclei in the brain stem. ${ }^{9}$ More recent research using neuroimaging has shown these specific nuclei (raphe nuclei, locus coeruleus, periaqueductal grey) to be selectively activated in the brain stem of migraine patients during a spontaneous migraine attack. ${ }^{10}$ These nuclei are involved in signal integration within pathways that modulate craniovascular status and that provide endogenous pain control. This pattern of activation appears to be unique to migraineurs since similar patterns are not as pronounced in cluster headache (much lower significance scores in brain stem than hypothalamic gray $)^{11}$ nor seen in experimental capsaicin-induced clinical head pain. ${ }^{12}$ Most recently, MRI studies have also revealed that the red nucleus and the brain stem dopaminergic region of the substantia nigra may become activated in concert with the occipital cortex during the visual aura of migraine. ${ }^{13}$ It was suggested that dysfunction in these brain stem nuclei could also be involved in a perturbation of endogenous pain control systems and underlie the disturbances in autonomic gastrointestinal dopaminergic functions associated with migraine. It is noteworthy that migraineurs are supersensitive to the dopamine agonist apomorphine, ${ }^{14}$ and that dopamine antagonists primarily relieve the gastrointestinal stasis and nausea associated with a migraine attack. ${ }^{15,16}$ Whilst this observation offers a potential explanation for the efficacy of dopamine antagonists such as prochlorperazine and metoclopramide in migraine therapy, the changes in these dopaminergic nuclei were not sustained during the headache pain phase, which is when these drugs are commonly given in the emergency room setting.

Current opinion is therefore that migraine is a 'neurovascular' disorder. In migraineurs, it is proposed that genetic abnormalities cause an inability to handle migraine trigger factors adequately and result in a primary neural dysfunction within the CNS. Indeed, studies have shown that the brain of migraineurs has altered responsivity to transcranial magnetic stimulation. ${ }^{17,18}$ The central dysfunction probably then activates brain stem autonomic nuclei, that then initiate the processes that lead to headache pain. ${ }^{6}$ The early studies of Harold Wolff ${ }^{19,20}$ showed that the brain itself was relatively insensate, whereas stimulation of the intracranial extracerebral vasculature was associated with acute pain. The generation of migraine headache pain is now thought to involve CNS dysfunction that leads to dilatation of the vasculature in intracranial extracerebral tissues and a consequent activation of the trigeminal sensory nerves that then relay pain signals to the brain.

\section{Trigeminovascular Pathophysiology OF HEADACHE PAIN}

Although the central processes involved in the initiation of a migraine attack are relatively poorly understood, considerably more is known about the factors involved in the pathophysiology of migraine headache pain. The brain has a sparse sensory innervation and, like other viscera, it is the capsule structures (meninges) that are the most significant pain producing intracranial tissues. ${ }^{21,22,23}$ Primarily the ophthalmic division of the trigeminal nerve ( $\mathrm{V}$ cranial nerve) innervates the meninges. The trigeminal nerves arise from pseudo-unipolar neurones in the trigeminal ganglia and project to the intracranial extracerebral blood vessels in the meninges (peripheral terminals) and behind the blood brain barrier into the trigeminal nuclei in the brain stem and upper cervical spinal cord (central terminals). These fibres therefore provide a pathway for pain signal transmission from meningeal blood vessels into the brain where headache pain is registered. This system has been described collectively as the 'trigeminovascular' system.

Our understanding of the pathophysiological mechanisms involved in migraine pain has been enhanced by increased knowledge of the serotonin receptor distribution within the trigeminovascular system and their functional pharmacology. This has been driven by the introduction of highly effective acute anti-migraine drug therapies and in particular, the selective serotonin receptor agonists that have become collectively known as the triptans. The 5-HT $\mathrm{H}_{1 \mathrm{~B} / 1 \mathrm{D}}$ agonists currently available for clinical use are sumatriptan (Imitrex ${ }^{\circledR}$ ), rizatriptan (Maxalt ${ }^{\circledR}$ ) naratriptan $\left(\right.$ Amerge $\left.^{\circledR}\right)$ and zolmitriptan $\left(\right.$ Zomig $\left.^{\circledR}\right)$ with eletriptan a fifth entrant currently in the late stages of the regulatory approval process. 


\section{MigRAine TREATMENT STRATEGIES}

There are several possible anti-migraine approaches that could be followed based on the scheme for migraine pathophysiology that has been proposed above.

For example, migraine prophylactic agents could inhibit the central processes involved in the initiation of a migraine attack or prevent meningeal vasodilatation and so stop the occurrence of migraine pain. Indeed, it has been speculated that the key mode of action of sodium valproate is to enhance activity within central inhibitory pathways by promoting the release of the neurotransmitter GABA through a blocking action at terminal ion channels. Calcium channel antagonists such as verapamil and flunarizine reduce neuronal activation directly by blocking voltage gated calcium channels. The serotonin antagonist antimigraine agents (e.g. pizotifen, methysergide) have been suggested to block the initial meningeal vasodilator step in the migraine pathogenesis pathway through blocking $5-\mathrm{HT}_{2 \mathrm{~B}}$ receptors that have been proposed to mediate a nitric oxide dependent vasodilatation. ${ }^{24}$ Indeed, there have been strong arguments for a pivotal role for nitric oxide (NO) in mediating the vasodilator and inflammatory effects of vasoactive neuropeptides and in the sensitization of perivascular sensory nerves. ${ }^{25}$ In support of this hypothesis, it has been observed that migraineurs are supersensitive to NO-donors such as glyceryl trinitrate $^{26}$ and there is preliminary evidence that NO-synthase inhibitors may be effective anti-migraine agents. ${ }^{27}$ The mode of action of the adrenergic $\beta$-blockers (propranolol, metoprolol, nadolol) and brain penetrant serotonin antagonists is also likely to be central by inhibition of the monoaminergic nuclei (raphe nuclei (5-HT) and locus coeruleus (NE)) that become activated at the onset of an attack, thereby preventing disturbances in vascular control systems. Older agents such as amitriptyline also work centrally but it is difficult to discern the critical mechanism involved in their actions because of their rich receptor and ion channel pharmacology. It is clear, however, that all these prophylactic strategies are of little value once a migraine attack has progressed to the point at which the trigeminovascular system has become activated. At this time then, a different therapeutic approach is needed to reverse migraine headache pain.

\section{KEY STEPS IN MIGRAINE HEADACHE PAIN}

Current theories suggest that after an initial CNS dysfunction, there are three key processes in the generation of migraine headache pain. These mechanisms have been carefully studied in the clinic and with experimental models. The first key process is thought to involve meningeal blood vessel dilation..$^{20,28}$ As the arteries swell, they activate perivascular sensory trigeminal nerves causing pain impulses to be transmitted to the caudal brain stem nuclei. Activation of these nerve terminals triggers the second key process in migraine - a release of vasoactive neuropeptides. ${ }^{21,29}$ These substances worsen and perpetuate vasodilatation, setting up a vicious cycle that increases meningeal blood vessel diameter further, thereby increasing nerve activation and intensifying headache pain. The most notable of these peptides is substance $\mathrm{P}$, neurokinin $\mathrm{A}$ and calcitonin gene-related peptide (CGRP) ${ }^{30}$ Substance $\mathrm{P}$ primarily increases blood vessel permeability (with transient dilation), neurokinin A has longer lasting effects on permeability and blood vessel calibre whereas CGRP produces a profound and long lasting vasodilatation but has no effects on blood vessel permeability. Indeed, the vasodilator effects of CGRP potentiate the permeability effects of the neurokinins. Their effects are mediated primarily by endothelial neurokinin $1\left(\mathrm{NK}_{1}\right)$ receptors and nitric oxide release (substance $\mathrm{P}$ ) and by actions directly on vascular smooth muscle (CGRP). The third key event involves the relay of pain impulses from the activated peripheral sensory nerves to second order sensory neurones within trigeminal nuclei in the caudal brain stem and upper cervical spinal cord (trigeminocervical complex). ${ }^{31}$ It has been hypothesized that these central sensory neurones may become sensitized during migraine. This sensitization may be responsible for the intensification of headache pain as an attack progresses and for an increased sensitivity to convergent sensory stimuli from extracranial tissues. ${ }^{32,33,34}$ The trigeminal sensitization process may underlie the facial sensory disturbances that are sometimes associated with migraine and perhaps also underpins its transformation in some individuals to a more chronic condition. The trigeminal nuclei are then responsible for relaying incoming pain signals to higher cortical centres where migraine pain is registered. Symptoms commonly associated with a migraine attack such as nausea, phono and photophobia are produced when other associated central nuclei and pathways are activated.

An ideal acute anti-migraine therapy would target these three key processes occurring in the trigeminovascular system that give rise to headache pain. It is noteworthy that acute antimigraine agents that target the trigeminovascular system have little or no therapeutic value as prophylactics since this system is not in play until headache pain has started.

\section{5-HT 1 RECEPTOR SUBTYPE DISTRIBUTION IN TRIGEMINOVASCULAR PATHWAYS}

Vasoconstrictor 5-HT $T_{1 B}$ receptors. Detailed molecular biology mapping of mRNA and immunohistochemistry for receptor protein have shown conclusive evidence for substantial populations of $5-\mathrm{HT}_{1 \mathrm{~B}}$ receptors on human meningeal blood vessels. ${ }^{35,36}$ These receptors are localized on the smooth muscle and mediate vasoconstriction. The $5-\mathrm{HT}_{1 \mathrm{~B}}$ receptors are thus ideally placed to reverse the dilation of meningeal vessels that is thought to occur during a migraine attack. Evidence for $5-\mathrm{HT}_{1 \mathrm{~B}}$ receptors has also been found on human coronary arteries ${ }^{37}$ making it important to establish the relative contribution of this subtype to the contractile responses in coronary arteries as well as in the target meningeal blood vessels (see discussion below).

Vasodilator $5-\mathrm{HT}_{1 B}$ and $5-\mathrm{HT}_{7}$ receptors. It is fascinating to see that evidence is now emerging for $5-\mathrm{HT}_{1 \mathrm{~B}}$ and $5-\mathrm{HT}_{7}$ receptors on vascular endothelium which could mediate vasodilatation. These receptors could be involved in the pathogenesis of migraine by initiating the meningeal vasodilatation that activates the trigeminovascular system. It is therefore possible that a $5-\mathrm{HT}_{7}$ antagonist could be a migraine prophylactic agent. These vasodilator endothelial 5-HT receptors could also have a role in migraine headache recurrence with the serotonin agonist anti-migraine agents. Thus endothelial 5-HT and $5-\mathrm{HT}_{7}$ receptors could remain preferentially activated as plasma concentrations fall with time after dosing when $5-\mathrm{HT}_{1 \mathrm{~B}}{ }^{-}$ mediated vasoconstrictor effects diminish. It is interesting to 
speculate that $5-\mathrm{HT}_{1 \mathrm{~B}}$ and $5-\mathrm{HT}_{7}$ receptors could be the link to the vasculature for the early observations (decrease in platelet 5HT and increased urinary 5-HT metabolite 5-HIAA) that suggested serotonergic activation as a key early process in the initiation of a migraine attack.

Trigeminal inhibitory $5-H T_{1 D}$ and $5-H T_{1 F}$ receptors. Studies on the localization of 5- $\mathrm{HT}_{1 \mathrm{~B}}$ and $5-\mathrm{HT}_{1 \mathrm{D}}$ receptors in human trigeminal ganglia and trigeminal nerves have produced a series of interesting findings. Mapping studies in ganglia have been inconclusive, showing mRNA evidence either for both subtypes $^{38}$ or purely for $5-\mathrm{HT}_{1 \mathrm{D}}$ receptor expression. ${ }^{39,40}$ Immunohistochemical receptor protein mapping has shown that $5-\mathrm{HT}_{1 \mathrm{~B}}$ and 5-HT $\mathrm{HD}_{1 \mathrm{D}}$ receptors are present on cell bodies in human trigeminal ganglia. However, only 5- $\mathrm{HT}_{1 \mathrm{D}}$ receptors were detected in trigeminal nerves projecting peripherally to the dural vasculature and centrally to the brain stem trigeminal nuclei. ${ }^{36}$ Activation of such prejunctional receptors on nerve terminals is known to modulate neurotransmitter release. The 5- $\mathrm{HT}_{1 \mathrm{D}}$ receptors are thus ideally placed peripherally, to inhibit activated trigeminal nerves and promote normalization of blood vessel calibre by preventing vasoactive neuropeptide release and centrally, to interrupt pain signal transmission from the blood vessels to second order sensory neurones in the brain stem.

Interestingly, 5-HT $\mathrm{HD}_{1 \mathrm{D}}$ receptors were also localized within the solitary tract nucleus in the brain $\mathrm{stem}^{36}$ which receives trigeminal inputs and is involved in the autonomic regulation of nausea and vomiting - two effects often clinically important in migraine.

A trigeminal location has recently been described for $5-\mathrm{HT}_{1 \mathrm{~F}}$ receptors ${ }^{41}$ where its prejunctional pharmacological effects are thought likely to be similar to those of the $5-\mathrm{HT}_{1 \mathrm{D}}$ receptor (inhibition of sensory nerve activation and peptide release in the periphery and interruption of nociceptive transmission within central trigeminal nuclei). However, 5- $\mathrm{HT}_{1 \mathrm{~F}}$ receptors are also relatively abundant throughout the brain raising the possibility that its activation centrally may have other effects in addition to trigeminal inhibition. ${ }^{42} 5-\mathrm{HT}_{1 \mathrm{~F}}$ mRNA has also been demonstrated in human blood vessels although there appears to be no expression of functional receptors since $5-\mathrm{HT}_{1 \mathrm{~F}}$ agonists appear devoid of vascular effects. ${ }^{43}$

\section{5-HT RECEPTOR PROFILE OF ACUTE ANTI-MIGRAINE DRUGS}

The serotonin receptor family is currently grouped into seven subfamilies $\left(5-\mathrm{HT}_{1}\right.$ to $\left.5-\mathrm{HT}_{7}\right)$ and fourteen receptor subtypes that have different anatomical locations. ${ }^{44}$ The most common sites of action for effective serotonergic agonist acute anti-migraine drugs (ergots and the 5- $\mathrm{HT}_{1 \mathrm{~B} / 1 \mathrm{D}}$ agonists) appear to be through vasoconstrictor $5-\mathrm{HT}_{1 \mathrm{~B}}$ receptors on the meningeal vasculature and inhibitory $5-\mathrm{HT}_{1 \mathrm{D}}$ receptors on trigeminal nerve terminals.

Older anti-migraine compounds such as the ergot alkaloids have strong affinity for the anti-migraine $5-\mathrm{HT}_{1 \mathrm{~B}}$ and $5-\mathrm{HT}_{1 \mathrm{D}}$ receptors but they also retain high affinity for other serotonin, adrenergic and dopaminergic receptor subtypes (see Table ${ }^{45,46}$ ) that can potentially mediate unwanted nausea, dysphoria, asthenia and vascular effects. The triptan agents are a significant progression since they target only the anti-migraine $5-\mathrm{HT}_{1 \mathrm{~B}}$ and $5-\mathrm{HT}_{1 \mathrm{D}}$ receptors and have reduced or eliminated unwanted activity at most other monoamine receptor subtypes, thereby improving therapeutic tolerability. The main limitations with the ergotamine are nausea and vomiting that can exacerbate the gastrointestinal symptoms commonly occurring in migraine. These effects are reduced with dihydroergotamine but nausea is still prominent. The $5-\mathrm{HT}_{1 \mathrm{~B}}$ and $5-\mathrm{HT}_{1 \mathrm{D}}$ receptor specificity profile of the triptan agents currently in clinical use (sumatriptan, rizatriptan, zolmitriptan, and naratriptan) and those in development (eletriptan, frovatriptan, almotriptan) is broadly similar. ${ }^{46}$ The individual potencies of the $5-\mathrm{HT}_{1 \mathrm{~B} / 1 \mathrm{D}}$ agonists at 5$\mathrm{HT}_{1 \mathrm{~B}}$ and $5-\mathrm{HT}_{1 \mathrm{D}}$ receptors vary somewhat but this is usually reflected in the clinical dose, supporting the idea that activity at these receptors is primarily responsible for their therapeutic effects. Some differences between the triptan agents are also apparent in ancillary activity at $5-\mathrm{HT}_{1 \mathrm{~A}}, 5-\mathrm{HT}_{1 \mathrm{E}}$ and $5-\mathrm{HT}_{1 \mathrm{~F}}$ receptors 46,47 and these may be involved, together with their potency at $5-\mathrm{HT}_{1 \mathrm{~B} / 1 \mathrm{D}}$ receptors, in producing their individual efficacy tolerability profiles.

\section{ANTI-MIGRAINE MECHANISMS OF ACTION FOR THE 5-HT AGONISTS}

The figure shows diagrammatically the key sites of action for the $5-\mathrm{HT}_{1 \mathrm{~B} / 1 \mathrm{D}}$ agonist antimigraine agents. First is a vascular mechanism of action. The 5- $\mathrm{HT}_{1 \mathrm{~B} / 1 \mathrm{D}}$ agonists selectively constrict pain-producing intracranial extracerebral blood vessels by a direct action at $5-\mathrm{HT}_{1 \mathrm{~B}}$ receptors on the vascular smooth muscle. ${ }^{48}$ This effect reverses the vasodilatation and so reduces trigeminal sensory nerve activation during migraine. The 5$\mathrm{HT}_{1 \mathrm{~B} / 1 \mathrm{D}}$ agonists have good selectivity for the target blood vessels over others (e.g. coronary) that could mediate adverse effects (see below).

Second is a neurogenic mechanism of action probably at 5$\mathrm{HT}_{1 \mathrm{D}}$ receptors. ${ }^{49,50}$ The $5-\mathrm{HT}_{1 \mathrm{~B} / 1 \mathrm{D}}$ agonists inhibit peripheral trigeminal nerves and prevent neuropeptide release from the activated peripheral terminals thereby removing the influence of potent vasodilator peptides, particularly CGRP. This action breaks the dilator cycle of events that could intensify pain transmission and thereby promotes normalization of meningeal blood vessel calibre.

Third is a central mechanism of action probably at 5-HT receptors within brain stem sensory trigeminal nuclei. Brain penetrant $5-\mathrm{HT}_{1 \mathrm{~B} / 1 \mathrm{D}}$ agonists inhibit neurotransmitter release from the central terminals of activated trigeminal nerves. ${ }^{51,52}$ This action interrupts pain transmission from cranial structures that would otherwise pass through these central pain relay stations. Preclinical studies show that this action appears to be specific for trigeminal sensory divisions since $5-\mathrm{HT}_{1 \mathrm{~B} / 1 \mathrm{D}}$ agonists did not reduce pain transmission in the lumbar spinal dorsal horn ${ }^{53}-$ an observation that could explain why this class of compounds are not general analgesics. More recent studies have revealed that centrally acting $5-\mathrm{HT}_{1 \mathrm{~B} / 1 \mathrm{D}}$ agonists can also prevent dural vasodilatation-evoked sensitization of caudal trigeminal neurones ${ }^{34}$ a phenomenon that could underlie their effectiveness in reducing extracranial facial sensory disturbances during migraine. As an aside, it is interesting to note that opiates and nonsteroidal anti-inflammatory agents also inhibit this sensitization process and this may underlie their utility in migraine.

The relative importance of each of these mechanisms to migraine headache relief has been a subject of much discussion but it should be remembered that all could occur simultaneously. It is therefore likely that they act in a complementary manner to 
Table: Pharmacological activity of dihydroergotamine, ergotamine and rizatriptan at monoaminergic receptors except where specified.

\begin{tabular}{|c|c|c|c|c|c|c|c|c|c|c|c|c|c|}
\hline \multicolumn{14}{|c|}{ Serotonin receptors } \\
\hline & \multicolumn{2}{|c|}{$5-\mathrm{HT}_{1 \mathrm{~A}}$} & $\mathbf{5 - H T}$ 1в & \multicolumn{2}{|l|}{$5-\mathrm{HT}_{1 \mathrm{D}}$} & $5-\mathrm{HT}_{1 \mathrm{E}}$ & $5-\mathrm{HT}_{1 \mathrm{~F}}$ & \multicolumn{2}{|c|}{$5-\mathrm{HT}_{2 \mathrm{~A}}$} & $5-\mathrm{HT}_{2 \mathrm{C}}$ & $5-\mathrm{HT}_{3}$ & \multicolumn{2}{|r|}{$5-\mathrm{HT}_{4}$} \\
\hline DHE & 0.4 & & 0.7 & 0.5 & & & 180 & \multicolumn{2}{|c|}{9.0} & 1.3 & $>3700 \mathrm{r}$ & & 60 \\
\hline Ergot & 0.3 & & 1.0 & 0.8 & & & 170 & n.d. & & n.d. & $>3700 \mathrm{r}$ & & 65 \\
\hline \multirow[t]{3}{*}{ Rizatriptan } & 300 & & 7.2 & 2.3 & & & 138 & 7200 & & 7300 & 4100 & & n.d. \\
\hline & \multicolumn{7}{|c|}{ Adrenergic receptors } & \multicolumn{6}{|c|}{ Dopamine receptors } \\
\hline & & $\alpha \mathbf{1 a}$ & $\alpha \mathbf{1 b}$ & $\alpha \mathbf{2 a}$ & $\alpha 2 b$ & $\alpha 2 \mathrm{c}$ & $\beta 1$ & $\beta 2$ & $\beta 3$ & D2 & D3 & D4 & \\
\hline DHE & & 6.6 & 8.3 & 1.9 & 3.3 & 1.4 & 3100 & 2700 & 271 & 1.2 & 6.4 & 8.7 & \\
\hline Ergot & & 15 & 12 & n.d. & n.d. & n.d, & n.d. & n.d. & n.d. & 4 & 3.2 & 12 & \\
\hline Rizatriptan & & $>10,000$ & $>10,000$ & 2300 & 6000 & 700 & $>10,000$ & $>10,000$ & $>10,000$ & $>10,000$ & n.d. & $>10,0$ & 00 \\
\hline
\end{tabular}

Top rows are 5-HT receptors, 5- $\mathrm{HT}_{3}$ (rat) receptors and 5-HT (guinea pig) receptors. Second row are alpha ( $\alpha 1$ rat liver, $\alpha 2$ human prostate) and cloned beta adrenergic receptors and cloned dopamine D receptors. Data for rizatriptan at cloned 5-HT 1 receptor subtypes were modified from Pauwels et al. ${ }^{47}$ All values are affinity IC50 nM. n.d. - not determined.

reduce the intense trigeminal input that occurs during a migraine attack and so all contribute to the relief of migraine headache pain and associated symptoms.

\section{Central aCtions of the 5-HT 1B/1D $_{\text {AgOnists }}$}

There have been many debates on the importance of differences in the lipophilicity of the triptan agents and the effect that this has on oral absorption and brain penetration to the central terminals of the trigeminal nerves. It is, however, worth noting that all the 5- $\mathrm{HT}_{1 \mathrm{~B} / 1 \mathrm{D}}$ agonists currently in clinical use are very poorly brain penetrant when compared to agents like diazepam. It has been argued that the speed of absorption and access to the central sites could influence how fast the anti- migraine clinical response is achieved, but it is also likely that these factors will underlie the consistency of response and therefore the drug's overall effectiveness. There is one caveat to this argument and that is that the brain penetrability of the triptan agents have been determined experimentally in normal systems where the blood-brain barrier is intact. It has been speculated, but as yet unproven, that the blood-brain barrier may be open during migraine attack. It is not known whether this occurs early or late in an attack, but if it does, then clearly once it happens then all compounds will have equal access to central sites and differences between the various agents will disappear.

Trigeminal afferent fibres project to the solitary tract nucleus (NTS) that is involved in the emetic reflex. It follows that activation of this pathway during migraine may be the cause of

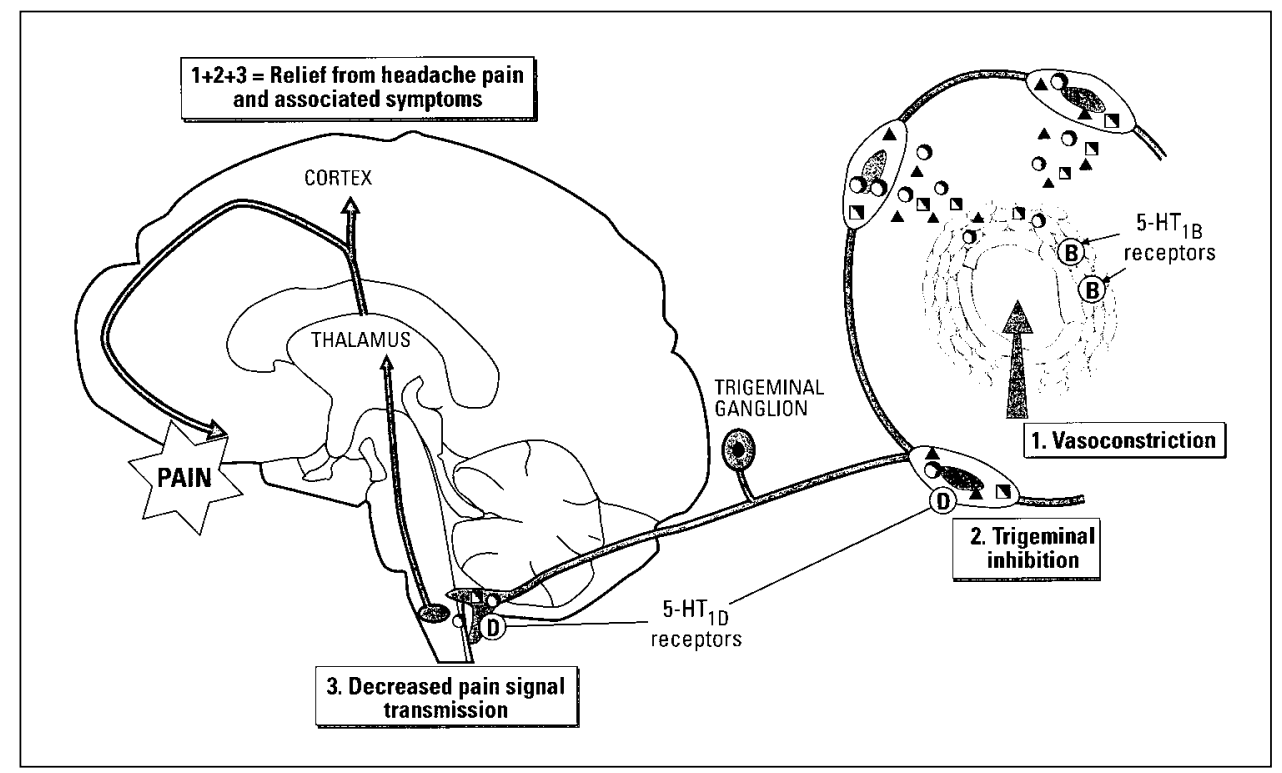

Figure: Three key actions of anti-migraine 5-HT $T_{1 B / I D}$ agonists in the relief of migraine headache pain: 1$)$ vasoconstriction through an action at 5-HT $T_{1 B}$ receptors on the vascular smooth muscle on meningeal blood vessels 2) inhibition of peripheral trigeminal perivascular sensory nerves preventing vasoactive (CGRP) neuropeptide release through an action at prejunctional 5-HT $T_{1 D}$ receptors and 3) inhibition of pain signal transmission within the brain stem trigeminal nucleus caudalis by preventing sensory neurotransmitter release through an action at 5-HT $T_{1 D}$ receptors on central trigeminal nerve terminals. 
migraine-associated nausea and vomiting. The 5- $\mathrm{HT}_{1 \mathrm{~B} / 1 \mathrm{D}}$ agonists have been shown to decrease nausea and vomiting and this is likely to be an indirect effect of reducing trigeminal input to the NTS. Fast drug penetration to central sites may bring additional benefits for the triptan agents by giving access to 5$\mathrm{HT}_{1 \mathrm{D}}$ receptors in the solitary tract nucleus. It is therefore noteworthy that the more brain penetrant $5-\mathrm{HT}_{1 \mathrm{~B} / 1 \mathrm{D}}$ agonists such as rizatriptan have some of the fastest effects against migraine associated nausea. ${ }^{54}$ However, it is important to remember that any benefit here could be offset by simultaneous activity at central 5-HT $\mathrm{HA}_{1 \mathrm{~A}}$ receptor sites, since these may be pro-nauseant. The window between activity at $5-\mathrm{HT}_{1 \mathrm{D}}$ and $5-\mathrm{HT}_{1 \mathrm{~A}}$ receptors should therefore be maximized for the greatest anti-nausea therapeutic gain. Remember that recent preclinical studies ${ }^{55}$ suggest that agonist actions at central $5-\mathrm{HT}_{1 \mathrm{~A}}$ receptors are unlikely to contribute to the anti-nociceptive effects of the 5$\mathrm{HT}_{1 \mathrm{~B} / 1 \mathrm{D}}$ agonists in trigeminal nuclei, in contrast to their analgesic effects in spinal dorsal horn.

\section{All TRIPAN 5-HT 1B/1D $_{\text {RECEPTOR AGONISTS ARE PARTIAL }}$ AGONISTS IN HUMAN CORONARY ARTERIES}

The demonstration that $5-\mathrm{HT}_{1 \mathrm{~B}}$ receptors are present in the coronary arteries has given rise to concern over the potential for adverse cardiac events with the ergots and the 5-HT $1 \mathrm{~B} / 1 \mathrm{D}$ agonists and has resulted in this class of drugs being contraindicated for use in cardiovascular risk patients. Adverse cardiac events are, however, rare with all the 5- $\mathrm{HT}_{1 \mathrm{~B} / 1 \mathrm{D}}$ agonists for two reasons. First, the 5- $\mathrm{HT}_{1 \mathrm{~B}}$ receptor reserve appears to be lower in the coronary than the meningeal arteries. ${ }^{37}$ Second, collectively all the triptan 5- $\mathrm{HT}_{1 \mathrm{~B} / 1 \mathrm{D}}$ receptor selective agonists lack activity at $5-\mathrm{HT}_{2 \mathrm{~A}}$ receptors ${ }^{46,47}$ which mediate most of the serotonergic contraction in coronary vessels. ${ }^{56}$ Taken together, these factors confer craniovascular selectivity and cardiovascular safety for the triptan class. At therapeutic concentrations there are no marked differences between the triptan 5- $\mathrm{HT}_{1 \mathrm{~B} / 1 \mathrm{D}}$ selective agonists in their contractile effects on human coronary arteries in vitro. ${ }^{57}$ It is noteworthy that all the agents in the triptan class are partial agonists in human coronary blood vessels in vitro ${ }^{57,58}$ as their maximum effects are only a small fraction of the response that can be evoked by the endogenous ligand serotonin. Any small differences between the responses to the various triptan agents reflects their relative therapeutic potency and occur at high concentrations that are supramaximal clinically and therefore irrelevant to their therapeutic use against migraine.

There has been much discussion comparing the potential cardiovascular safety of the various triptan compounds but the arguments have often confused the safety and tolerability aspects of their profiles. Although there may be differences in the tolerability profiles of the $5-\mathrm{HT}_{1 \mathrm{~B} / 1 \mathrm{D}}$ agonists, their potential coronary safety profiles, as judged by pharmacological studies, appear basically indistinguishable at this time.

\section{NOVEL APPROACHES TO ACUTE MIGRAINE THERAPY}

Several recent drug development projects have been directed towards blockade of the prejunctional effects i.e. release of vasoactive peptides from activated trigeminal nerves, in the hope of discovering acute anti-migraine agents that lack the postjunctional vasoconstrictor effects of the 5-HT $\mathrm{H}_{1 \mathrm{~B} / 1 \mathrm{D}}$ agonists. The substance $\mathrm{P} \mathrm{NK}_{1}$ receptor antagonists (LY303870, RP100,893 GR205,171 and L-758,298) have failed in clinical trials for acute migraine treatment and, although disappointing, this finding is of interest with regard to the migraine pathogenesis theory. ${ }^{59}$ Experimental studies show that neurogenic extravasation/inflammation in the meninges is mediated by neurokinins acting at $\mathrm{NK}_{1}$ receptors on the vascular endothelium. ${ }^{60}$ If this neurogenic extravasation occurs in migraine, then it should have been completely blocked by these agents. These data suggest that theories encompassing a role for ongoing neurogenic dural extravasation in the headache pain phase of migraine may have to be re-evaluated perhaps by examining the activity of these agents as prophylactics. Attention has now been directed towards CGRP-induced meningeal vasodilatation as a primary factor in producing migraine headache pain. Increased CGRP levels are perhaps one of the most reliable biochemical markers in migraine and cluster headache and levels are normalized concomitant with successful therapy. ${ }^{30}$ CGRP antagonists have been shown experimentally to block meningeal artery vasodilatation, ${ }^{61}$ suggesting that they may have antimigraine activity. Non-peptide, CGRP antagonists are thought to be in early clinical trials.

These antagonist approaches involve postjunctional blockade of only one of the vasoactive substances that are released when the trigeminal nerves are activated and, since many substances are released, this strategy runs the risk that the other unblocked components can still be active in the migraine process. A more complete approach is to target prejunctional receptors on the trigeminal nerve terminals to prevent the release of all vasoactive substances at the same time. Immunohistochemical and mRNA studies in human tissues have shown that it is the 5-HT receptor that is selectively located on the perivascular and central terminals of trigeminal fibres. ${ }^{36}$ As a result it has been suggested that a $5-\mathrm{HT}_{1 \mathrm{D}}$ selective agonist (effectively a sensory neuropeptide-release inhibitor) would be an attractive drug target since it could potentially modulate transmission in the trigeminal pathways but lack the $5-\mathrm{HT}_{1 \mathrm{~B}}$ mediated vasoconstrictor activity of current triptan anti-migraine agents. Recent reports also suggest that $5-\mathrm{HT}_{1 \mathrm{D}}$ receptors may modulate glutamatergic transmission in the cerebral cortex in vitro ${ }^{62}$ and if this occurs in the medullary dorsal horn, then it may be important in the central anti-nociceptive actions of the 5-HT $1 \mathrm{~B} / 1 \mathrm{D}$ agonists and 5-HT receptor selective agonists. The $5-\mathrm{HT}_{1 \mathrm{D}}$ receptor selective agonist PNU 142,633 recently completed have entered Phase II clinical trials and the data showed no evidence for acute efficacy against migraine (R. McCall, personal communication, IBC Migraine Conference Philadelphia, May 1999). This finding was disappointing since the rationale for the development of these compounds appears sound. The reason for the failure is probably that PNU 142,633 lacked sufficient efficacy at 5-HT 1 receptors (approximately one third the efficacy of sumatriptan at gorilla cloned $5-\mathrm{HT}_{1 \mathrm{D}}$ receptors) and so was unable to shut down the activated sensory nerves during migraine. ${ }^{63}$ It should be remembered that the actions of the serotonin agonists to inhibit neurotransmitter peptide release will be frequency dependent such that the harder the nerves are firing the harder it is to inhibit them. The 5-HT 1 hypothesis thus remains untested and requires re-evaluation with a compound with equally full efficacy at 5- 
$\mathrm{HT}_{1 \mathrm{D}}$ receptors as the currently used 'triptan' agents but lacking activity at $5-\mathrm{HT}_{1 \mathrm{~B}}$ receptors.

Several of the current triptan agents have affinity for $5-\mathrm{HT}_{1 \mathrm{~F}}$ receptor sites and it has been proposed that this may contribute to their anti-migraine efficacy. ${ }^{64}$ The development of $5-\mathrm{HT}_{1 \mathrm{~F}}$ receptor selective agonists has been underpinned by the same lines of argument that were used for the 5-HT $\mathrm{HD}_{1 \mathrm{D}}$ selective strategy, since functional $5-\mathrm{HT}_{1 \mathrm{~F}}$ receptors appear to be present on peripheral trigeminal nerve terminals but absent from blood vessels. The most advanced compound in this class is LY334370. ${ }^{65}$ This compound has been recently withdrawn from phase III clinical trials, due to animal toxicity. Preliminary phase II data on the efficacy of LY 334370 were recently presented at the International Headache Society in Barcelona and looked promising with anti-migraine efficacy being demonstrated at 60 and $200 \mathrm{mg}$ doses. ${ }^{66}$ It remains to be established whether this is due to activity solely at $5-\mathrm{HT}_{1 \mathrm{~F}}$ receptors, as the plasma concentrations after $200 \mathrm{mg}$ of LY334370 were quite high, ${ }^{67}$ raising the possibility that selectivity may have been compromised. Further studies with this class are clearly warranted.

Further clinical trials to determine the effectiveness of 5$\mathrm{HT}_{1 \mathrm{D}}$ or the $5-\mathrm{HT}_{1 \mathrm{~F}}$ receptor selective agonists as anti-migraine agents will help settle the long-running debate on the relative importance of vasoconstriction and trigeminal inhibition to the anti-migraine effects of the "triptan" $5-\mathrm{HT}_{1 \mathrm{~B} / 1 \mathrm{D}}$ agonists. The success of these strategies is likely to be critically dependent upon adequate brain penetration to central trigeminal sites to interrupt trigeminal pain signal transmission. It will be most interesting if only one of these approaches shows anti-migraine efficacy, since this will redefine the anti-migraine neuropharmacology of the trigeminovascular system and perhaps reveal other neural components as novel therapeutic targets. Future antimigraine strategies will undoubtedly examine the relationship of $\mathrm{P} / \mathrm{Q}$ calcium ion channel mutations to brain dysfunction and perhaps target this as a migraine prophylactic strategy. In addition, the findings of 'wind up' in the trigeminal dorsal horn that can be driven by meningeal dilation and inflammation suggests that drugs that target this sensitization process may have a role in anti-migraine therapy.

\section{REFERENCES}

1. Ophoff RA, Terwindt GM, Vergouwe MN, et al. Familial hemiplegic migraine and episodic ataxia type- 2 are caused by mutations in the Ca2+ channel gene CACNL1A4. Cell 1996;87: 543-552.

2. Frants RR, Ophoff RA, Terwindt GM. The future of headache genetics. In: Olesen J, Bouser M-G, eds. Genetics of Headache Disorders. New York: Lippincott-Raven, 1998.

3. Hans M, Luvisetto S, Williams ME, et al. Functional consequences of mutations in the human $\alpha 1 \mathrm{~A}$ calcium channel subunit linked to familial hemiplegic migraine. J Neurosci 1999;19: 1610-1619.

4. Ferrari M. Migraine. Lancet 1998;351: 1043-1051.

5. Lauritzen M. Pathophysiology of the migraine aura: the spreading depression theory. Brain 1994;117: 199-210.

6. Welch KMA. Pathogenesis of migraine. Sem Neurol 1997;17: 335341.

7. Cutrer FM, Sorensen G, Weisskof R, et al. Perfusion weighted imaging defects during spontaneous migraine aura. Ann Neurol 1998;43: 25-31.

8. Read SJ, Parsons AA. Cortical spreading depression in migraine. In: Edvinsson L, ed. Migraine and Headache Pathophysiology. London: Martin Dunitz, 1999: 81-92.
9. Raskin NH, Hosobuchi Y, Lamb S. Headache may arise from perturbation of the brain. Headache 1987;27:416-420.

10. Weiller C, May A, Limmroth V, et al. Brain stem activation in spontaneous human migraine attacks. Nature Med 1995;1: 658660.

11. May A, Bahra A, Buchel C, Frackowy PJ. Hypothalamic activation in cluster headache attacks. Lancet 1998;352: 275-278.

12. May A, Kaube H, Buchel C, et al. Experimental cranial pain elicited by capsaicin: a PET study. Pain 1998;74: 61-66.

13. Welch KMA, Cao Y, Aurora S, et al. MRI of the occipital cortex, red nucleus and substantia nigra during visual aura of migraine. Neurology 1998; 51: 1465-1469.

14. Cerbo R, Barbanti P, Buzzi MG, et al. Dopamine hypersensitivity in migraine: role of the apomorphine test. Clin Neuropharmacol 1997;20:36-41.

15. Peroutka SJ. Dopamine and migraine. Neurology 1997;49: 12311238.

16. Dahlof CGH, Hargreaves RJ. Pathophysiology and pharmacology of migraine. Is there a place for anti-emetics in future treatment strategies? Cephalalgia 1998;18: 593-604.

17. Aurora SK, Ahmad BK, Welch KM, Bhardhwaj P, Ramadan NM. Transcranial magnetic stimulation confirms hyperexcitability of occipital cortex in migraine. Neurology 1998;50:1111-1114.

18. Afra J, Mascia A, Gerard P, Maertens de Noordhout A, Schoenen J. Interictal cortical excitability in migraine: a study using transcranial magnetic stimulation of motor and visual cortices. Ann Neurol 1998;44: 209-215.

19. Ray BS, Wolff HG. Experimental studies on headache: pain sensitive structures of the head and their significance in headache. Arch Surgery 1940;41: 813-856.

20. Wolff HG. Headache and Other Head Pain. New York: Oxford University Press, 1963.

21. Moskowitz MA. The neurobiology of vascular head pain. Ann Neurol 1984;16: 157-168.

22. Moskowitz MA. The visceral organ brain: implications for the pathophysiology of vascular head pain. Neurology 1991;41: 182-186.

23. Gebhart GF. Visceral pain mechanisms: relevance to migraine. In: Olesen J, Moskowitz MA, eds. Experimental Headache Models. Philadelphia: Lippincott-Raven Publishers, 1995:39-47.

24. Fozard JR. 5-hydroxytryptamine and nitric oxide: the causal relationship between two endogenous precipitants of migraine. In: Sandler M, Ferrari $M$ and Harnett S, eds. Migraine Pharmacology and Genetics. Chapman and Hall: London, 1996:167-179.

25. Olesen J, Thomsen LL, Iversen H. Nitric oxide is a key molecule in migraine and other vascular headaches. Trends Pharmacol Sci 1994;15: 149-153.

26. Thomsen LL, Olesen J. Experimental vascular headache models in man. In: Edvinsson L, ed. Migraine and Headache Pathophysiology. London: Martin Dunitz, 1999:141-154.

27. Lassen LH, Ashina M, Christiansen I, Ulrich V, Olesen J. Nitric oxide synthase inhibition in migraine. Lancet 1997;349: 401.

28. Humphrey PP, Feniuk W. Mode of action of the anti-migraine drug sumatriptan. Trends Pharmacol Sci 1991;12:444-446.

29. Goadsby PJ, Edvinsson L, Ekman R. Vasoactive neuropeptide release in the extracerebral circulation during migraine headache. Ann Neurol 1990;28:183-187.

30. Goadsby PJ, Edvinsson L. The trigeminovascular system and migraine: studies characterizing cerebrovascular and neuropeptide changes seen in humans and cats. Ann Neurol 1993;33:48-56.

31. Goadsby PJ, Zagami AS, Lambert GA. Neural processing of craniovascular pain: a synthesis of the central structures involved in migraine. Headache 1991;31: 365-371.

32. Strassman AM, Raymond SA, Burstein R. Sensitization of meningeal sensory neurons and the origin of headaches. Nature 1996;384: 560-564.

33. Burstein R, Yamamura H, Malick A, Strassman AM. Chemical stimulation of the intracranial dura induces enhanced responses to facial stimulation in brain stem trigeminal neurons. J Neurophysiol 1998;79: 964-982.

34. Cumberbatch MJ, Williamson DJ, Mason GS, Hill RG, Hargreaves 
RJ. Dural vasodilation causes a sensitization of rat caudal trigeminal neurones in vivo that is blocked by a $5-\mathrm{HT}_{1 \mathrm{~B} / \mathrm{D}}$ agonist. Br J Pharmacol 1999;126:1478-1486.

35. Hamel E, Fan E, Linville D, et al. Expression of mRNA for the serotonin 5-hydroxytryptamine ${ }_{1 \mathrm{D} \beta}$ receptor subtype in human and bovine cerebral arteries. Mol Pharmacol 1993;44:242-246.

36. Longmore J, Shaw D, Smith D, et al. Differential distribution of 5$\mathrm{HT}_{1 \mathrm{D}^{-}}$and $5-\mathrm{HT}_{1 \mathrm{~B}}$-immunoreactivity within the human trigemino-cerebrovascular system: implications for the discovery of new anti-migraine drugs. Cephalalgia 1997;17:835-842.

37. Longmore J, Razzaque Z, Shaw D, et al. Comparison of the vasoconstrictor effects of rizatriptan and sumatriptan in human isolated cranial arteries: immunohistochemical demonstration of the involvement of 5- $\mathrm{HT}_{1 \mathrm{~B}}$ receptors. Br J Clin Pharmacol 1998;46: 577-582.

38. Bouchelet I, Cohen Z, Case B, Seguela P, Hamel E. Differential expression of sumatriptan-sensitive 5-hydroxytryptamine receptors in human trigeminal ganglia and cerebral blood vessels. Mol Pharmacol 1998;50:219-223.

39. Rebeck GW, Maynard KI, Hyman BT, Moskowitz MA. Selective 5$\mathrm{HT}_{1 \mathrm{D}}$ serotonin gene receptor expression in trigeminal ganglia. Proc Natl Acad Sci USA 1994;91:3666-3669.

40. Bruinvels AT, Landwehrmeyer B, Gustafson EL, et al. Localization of $5-\mathrm{HT}_{1 \mathrm{~B}}, 5-\mathrm{HT}_{1 \mathrm{D} \alpha}, 5-\mathrm{HT}_{1 \mathrm{E}}$ and $5-\mathrm{HT}_{1 \mathrm{~F}}$ receptor messenger RNA in rodent and primate brain. Neuropharmacology 1994;33: 367-386.

41. Pascual J, Castro ME, Romon T, et al. Anatomical distribution of 5$\mathrm{HT}_{1 \mathrm{~F}}$ receptors in the human brain suggests a role in migraine. Cephalalgia 1997; 17:341.

42. Castro ME, Pascual J, Romon T,et al. Differential distribution of $\left[{ }^{3} \mathrm{H}\right]$ sumatriptan binding sites $\left(5-\mathrm{HT}_{1 \mathrm{~B}}, 5-\mathrm{HT}_{1 \mathrm{D}}\right.$ and $5-\mathrm{HT}_{1 \mathrm{~F}}$ receptors) in human brain: focus on brain stem and spinal cord. Neuropharmacology 1997;36:535-542.

43. Cohen ML, Johnson KW, Schenck KW. Lack of vasoconstriction to the selective 5-HT ${ }_{1 \mathrm{~F}}$ receptor agonists LY334370 and LY344864 in the rabbit saphenous vein (RSV), a model for coronary and cerebral vasoconstrictor activity. Proceedings of the 4th IUPHAR satellite meeting on Serotonin, 23-25th July, Rotterdam, 1998:38.

44. Hoyer D, Clarke DE, Fozard JR, et al. The IUPHAR classification of receptors for 5-hydroxytriptamine (serotonin). Pharmacol Rev 1994;46:157-204.

45. Silberstein SD. The pharmacology of ergotamine and dihydroergotamine. Headache 1997;37(suppl. 1) S15-S25.

46. Martin GR, Rohdes P, Mills A. Autoradiographic mapping of receptors and recognition sites for established and putative antimigraine drugs. In: Edvinsson L, ed, Migraine and Headache Pathophysiology. London: Martin Dunitz, 1999:63-80.

47. Pauwels PJ, Tardif S, Palmier C, Wurch T, Colpaert FC. How efficacious are 5- $\mathrm{HT}_{1 \mathrm{~B} / 1 \mathrm{D}}$ receptor ligands: an answer from GTPgS binding studies with stably transfected C6-glial cell lines. Neuropharmacology 1997;36: 499-512.

48. Longmore J, Dowson AJ, Hill RG. Current Opinion in CPNS Investigational Drugs 1999;1:39-53.

49. Shepheard SL, Williamson DJ, Beer MS, Hill RG, Hargreaves RJ. Differential effects of 5-HT $\mathrm{HB}_{1 \mathrm{D} / \mathrm{D}}$ receptor agonists on neurogenic dural plasma extravasation and vasodilation in anaesthetized rats. Neuropharmacology 1997;36: 525-533.

50. Williamson DJ, Hargreaves RJ, Hill RG, Shepheard SL. Intravital microscope studies on the effects of neurokinin agonists and calcitonin gene-related peptide on dural vessel diameter in the anaesthetized rat. Cephalalgia 1997;17:518-524.
51. Kaube H, Hoskin KL, Goadsby PJ. Inhibition by sumatriptan of central trigeminal neurones only after blood-brain barrier disruption. Br J Pharmacol 1993;109:788-792.

52. Cumberbatch MJ, Hill RG, Hargreaves RJ. Rizatriptan has central antinociceptive effects against durally evoked responses. Eur J Pharmacol 1997;328:37-40.

53. Cumberbatch MJ, Hill RG, Hargreaves RJ. Differential effects of naratriptan on spinal versus trigeminal nociceptive responses. Cephalalgia 1997;17:381.

54. Tfelt-Hansen P, Teall J, Rodriguez F, et al. Oral rizatriptan versus oral sumatriptan: a direct comparative study in the acute treatment of migraine. Headache 1998;38:748-755.

55. Cumberbatch MJ, Hill RG, Hargreaves RJ. The effects of 5-HT ${ }_{1 A}$, $5-\mathrm{HT}_{1 \mathrm{~B}}$ and $5-\mathrm{HT}_{1 \mathrm{D}}$ receptor agonists on trigeminal nociceptive neurotransmission in anesthetized rats. Eur J Pharmacol 1998; 362:43-46.

56. Connor HE, Fenuik W, Humphrey PPA. 5-Hydroxytryptamine contracts human coronary arteries predominantly via $5-\mathrm{HT}_{2}$ receptor activation. Eur J Pharmacol 1989;161:91-94.

57. MaassenVanDenBrink A, Reekers M, Bax WA, Ferrari MD, Saxena PR. Coronary side-effect potential of current and prospective anti-migraine drugs. Circulation 1998;98:25-30.

58. Longmore J, Hargreaves RJ, Boulanger CM, et al. Comparison of the vasoconstrictor properties of the $5-\mathrm{HT}_{1 \mathrm{D}}$ receptor agonists rizatriptan (MK-462) and sumatriptan in human isolated coronary artery: outcome of two independent studies using different experimental protocols. Functional Neurology 1997;12:1-9.

59. Hargreaves RJ, Williamson DJ, Shepheard SL. Neurogenic inflammation: relation to novel antimigraine drugs. In: Edvinsson L, ed. Migraine and Headache Pathophysiology. London: Martin Dunitz, 1999:93-102.

60. Shepheard SL, Williamson DJ, Hill RG, Hargreaves RJ. The nonpeptide neurokinin1 receptor antagonists RP67580 blocks neurogenic plasma extravasation in the dura mater of rats. $\mathrm{Br} \mathrm{J}$ Pharmacol 1993;108:11-12.

61. Williamson DJ, Shepheard SL, Hill RG, Hargreaves RJ. The novel anti-migraine agent rizatriptan inhibits neurogenic dural vasodilation and extravasation. Eur J Pharmacol 1997;328: 61-64.

62. Maura G, Marcoli M, Tortarolo M, Andrioli GC, Raiteri M. Glutamate release in human cerebral cortex and its modulation by 5-hydroxytriptamine acting at $\mathrm{h} 5-\mathrm{HT}_{1 \mathrm{D}}$ receptors. $\mathrm{Br} \mathrm{J}$ Pharmacol 1998; $123: 45-50$

63. Pregenzer JF, Alberts GL, Im WB, et al. Differential pharmacology between the guinea-pig and the gorilla 5-HT receptor as probed with isochromans $\left(5-\mathrm{HT}_{1 \mathrm{D}}\right.$-selective ligands). Br J Pharmacol 1999; $127: 468-472$

64. Johnson KW, Schaus JM, Durkin MM, et al. 5-HT ${ }_{1 F}$ receptor agonists inhibit neurogenic dural inflammation in guinea pigs. NeuroReport 1997;8:2237-2240

65. Schaus JM, Audia JE, Dressman BA. LY334370 is a high affinity, selective $5-\mathrm{HT}_{1 \mathrm{~F}}$ receptor agonist. Cephalalgia 1997;17:398.

66. Goldstein DJ, Roon KJ, Offen WW, et al. Migraine treatment with selective 5-HT HF $_{1 F}$ receptor agonist (SSOFRA) LY334370. Cephalagia 1999;19:318 (abstract Proceedings of the 9th Congress of the IHS, Barcelona, Spain, June 1999).

67. Pereira A, Granier LA, Vandenhende F, de Suray JM, Onkelinx C. Safety and pharmacokinetics of high doses of LY 334870, a selective serotonin $1 \mathrm{~F}$ receptor agonist (SSOFRA) during and outside an acute migraine attack. Cephalagia 1999;19:368 (abstract Proceedings of the 9th Congress of the IHS, Barcelona, Spain, June 1999). 